\title{
Cavitary Pulmonary Metastases of
Gallbladder Cancer: A Rare Case Report
}

\section{Safra Kesesi Kanserinin Kaviter Akciğer Metastazı: Nadir Bir Olgu Sunumu}

\author{
Mustafa Çalık', Saniye Göknil Çalık², Tahir Taha Bekçi, Yaşar Ünlü${ }^{4}$, Hıdır Esme
}

\begin{abstract}
A gallbladder carcinoma is extremely fatal malignant tumor. The occurrence of excavated lung metastases is rarely observed only in $4 \%$ of cases. Herein, we describe a case of cavitary pulmonary metastases of gallbladder cancer. A 69 year-old woman was admitted to our hospital for routine controls. Three years before, she underwent partial hepatectomy with enbloc resection of the gallbladder and dissection of regional lymph nodes. The patient was event-free during follow-up. At 32 months, thoracic CT revealed a cavitary lesion in the right lung. Metastasectomy and mediastinal lymph node dissection was performed. Patient was discharged on day 14 after surgery without any complications. To the best of our knowledge, a relatively small number of cases with metastatic lung tumors cavitation have been reported in the literature. The differential diagnosis should be made with caution in patients with a history of neoplastic disease. Early diagnosis and treatment increase survival.
\end{abstract}

Key words: Gallbladder, adenocarcinoma, cavitation, lung metastases.

\section{Özet}

Safra kesesi kanseri son derece ölümcül malign bir tümördür. Kaviter akciğer metastazları çok nadir ve olguların sadece \% 4'ünde görülür. Burada, safra kesesi kanserinin neden olduğu kaviter akciğer metastazı olgusunu sunmayı amaçladık. Altmış dokuz yaşında bayan hasta olağan kontrolleri için hastanemize başvurdu. Üç yıl önce, safra kesesi kanseri nedeniyle enblok safra kesesi ve parsiyel karaciğer rezeksiyonu ile bölgesel lenf nodu diseksiyonu yapılmış. Buna bağlı olarak 32 ay boyunca yapılan takipleri, son toraks bilgisayarlı tomografisinde sağ akciğerde kaviter lezyon ortaya çıkana kadar negatiffi. Metastazektomi ve mediastinal lenf nodu diseksiyonu yapıldı. Hasta komplikasyonsuz olarak ameliyat sonrası 14. günde taburcu edildi. Görece az sayıda kaviter metastatik akciğer kanseri bildirilmiştir. Ayırıcı tanı neoplastik hastalık öyküsü olan hastalarda dikkatle yapılmalıdır. Erken tanı ve tedaviyle sağ kalımın artacağına inanıyoruz.

Anahtar Sözcükler: Safra kesesi, adenokarsinom, kavitasyon, akciğer metastaz.

'Department of Thoracic Surgery, Konya Education and Research Hospital, Konya, Turkey

${ }^{2}$ Department of Emergency Medicine, Konya Education and Research Hospital, Konya, Turkey.

${ }^{3}$ Department of Pulmonary Medicine, Konya Education and Research Hospital, Konya, Turkey.

${ }^{4}$ Department of Pathology, Konya Education and Research Hospital, Konya, Turkey

\author{
${ }^{1}$ Konya Eğitim ve Araştırma Hastanesi, Göğüs Cerrahisi \\ Kliniği, Konya \\ ${ }^{2}$ Konya Eğitim ve Araştırma Hastanesi, Acil Kliniği, Konya \\ ${ }^{3}$ Konya Eğitim Ve Araştırma Hastanesi, Göğüs Hastalıkları \\ Kliniği, Konya \\ ${ }^{4}$ Konya Eğitim ve Araştırma Hastanesi, Patoloji Kliniği, Konya
}

Submitted (Başvuru tarihi): 22.12.2015 Accepted (Kabul tarihi): 20.01.2016

Correspondence (iletişim): Mustafa Çalık, Department of Thoracic Surgery, Konya Education and Research Hospital, Konya, Turkey

e-mail:drmcalik@hotmail.com 
Although gallbladder carcinomas (GBCs) which are treated by surgical resection with curative intent, show variations all over the world depending on geographic and ethnic differences, they have a poor prognosis (1). These tumors are the sixth most common malignancies among gastrointestinal cancers. A carcinoma of the gallbladder was first identified by Stoll in 1877 during an autopsy procedure. Although rare, it has a poor prognosis due to its anatomic position and non-specific symptoms (1-3). It is three times more common in women, and occurs in patients 65 years and older. Three out of four cases are accompanied with cholelitiasis. One-year survival rate of a $\mathrm{GBC}$ is about $10 \%(4,5)$. While curative treatment can be achieved with resection in patients with early disease, $90 \%$ of patients with advanced disease fail to achieve cure. Half of patients with a GBC also have lymph node and liver involvement with a shorter survival rate in months $(6,7)$. Although cavitation in primary lung cancer is common, cavitary lesions are usually rare in pulmonary metastases (8). In our case, we detected a cavitary pulmonary metastasis of the gallbladder and, performed surgery. This case was presented due to its rarity in the literature.

\section{CASE}

A 59-year-old female patient presented to the general surgery outpatient clinic with complaints of abdominal pain and nausea six month ago. She underwent cholecystectomy including hepatic segments 4 and 5 . She received postoperative chemotherapy and radiotherapy. A follow-up computed tomography (CT) of the thorax showed two nodules, the larger one measuring $5.5 \mathrm{~mm}$ in diameter laterally-and peripherally-located in the posterior segment of the right upper lobe of the lung, and a cavitary lesion of $20 \times 18 \mathrm{~mm}$ in size with a thick, but regular wall in the superior segment of the right lower lobe of the lung (Figure 1 and 2). Based on these findings, the patient underwent positron emission (PET) CT which revealed a slightly increased FDG uptake (SUVmax: 3.54) in a cavitary lesion of $18 \times 20 \mathrm{~mm}$ with a thick wall in the superior segment of the right lower lobe of the lung, and slightly increased FDG uptakes (SUVmax: 3.40) in lymph nodes reaching to $1 \mathrm{~cm}$ in diameter in the paratracheal, precarinal, and bilateral hilar regions of the mediastinum (Figure 3). No FDG affinity or associated pathological uptake was observed at the resolution limit in the nodule, measuring $6 \mathrm{~mm}$ in diameter in the posterior segment of the right upper lobe of the lung. Diagnostic fiberoptic bronchoscopy was made and reported as normal. The patient was scheduled for diagnostic thoracotomy. The cavitary lesion and nodule in the right upper lobe were removed by the wedge resection during surgery. The removed nodule and cavitary lesion were sent for frozen section. The frozen section report indicated that both lesions were malignant. The Department of Pathology suggested immunostaining to determine if the lesion was a metastasis of a primary lung cancer or gallbladder cancer (Figure 4). Therefore, the patient was scheduled for metastasectomy, and, then, mediastinal lymph node dissection was performed. Lymph nodes $4 a, 4 b, 10,11 a$, $11 \mathrm{~b}$, and 12 were removed and sent to pathology lab. As her overall condition improved, the patient was discharged on day 14 after surgery.

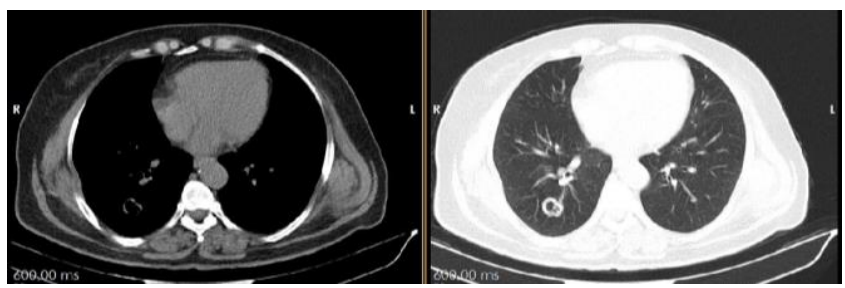

Figure 1: Thoracic CT scan revealed cavity in right hemithorax

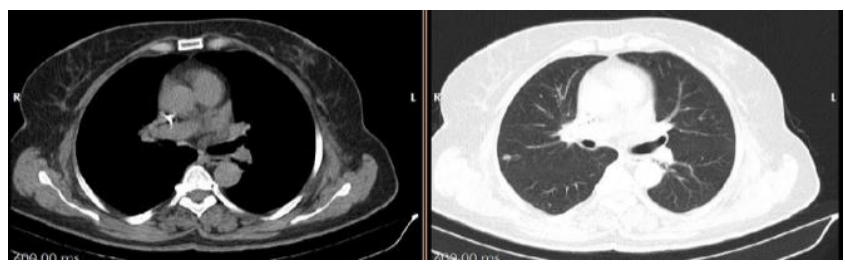

Figure 2: Thoracic CT scan showing nodule in right hemithorax

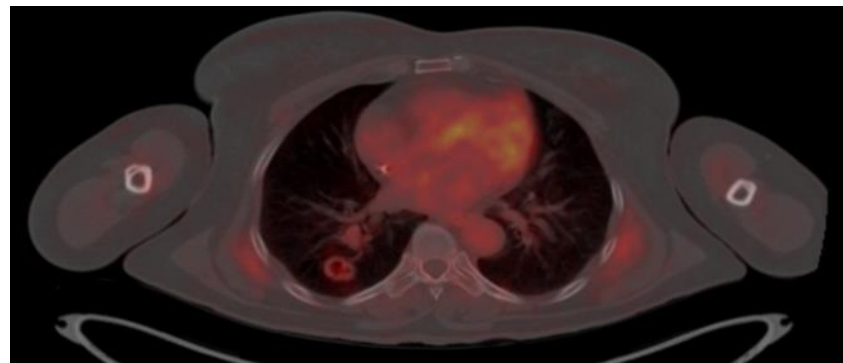

Figure 3: PET-CT showing metastatic cavitary lesion in right hemithorax

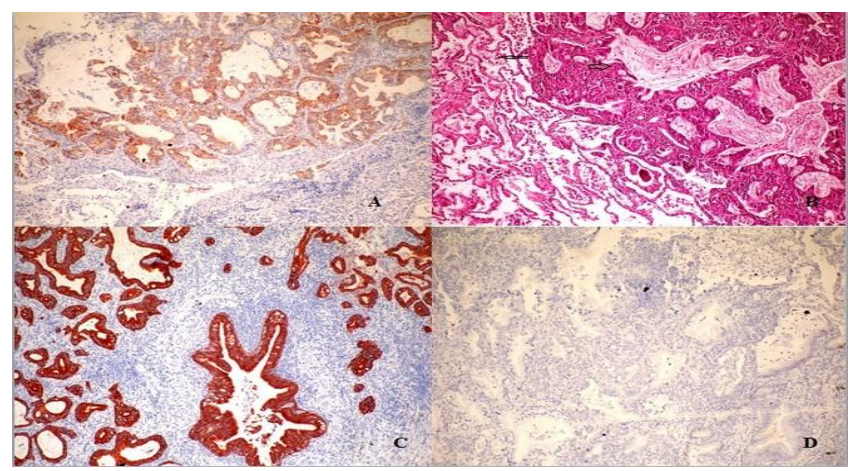

Figure 4a, b, $c$ and $d$ : CK7 immunoreactivity in tumor cells (A), metastatic tumor tissue (thick arrow) (B) (H\&E), CA immunoreactivity in tumor cells (C), TTF 1 immunoreactivity-negative in tumor cells (D) (X 200) 


\section{DISCUSSION}

A cavity has been defined in the radiology literature as "a gas-filled space within a zone of pulmonary consolidation or within a mass or nodule, produced by the expulsion of a necrotic part of the lesion via the bronchial tree" (pathologically) and "a lucency within a zone of pulmonary consolidation, a mass, or a nodule; hence, a lucent area within the lung that may or may not contain a fluid level and that is surrounded by a wall, usually of varied thickness" (radiographically). A cavity is the result of any of a number of pathological processes. One of them is malignant process such as lung metastasis (9). Lung represents a major metastatic site of the body, as there is a seat about 30 to $50 \%$ of all secondary locations. Cavitary lung metastases are rarely observed only in $4 \%$ of cases (10). Typically GBC occurs in older ages, and usually complicated with other diseases of the gallbladder, which may lead to misdiagnosis. In addition, GBCs are more common in women, while bile duct carcinomas are more common in men. Also, GBCs are histopathologically classified in four subgroups: adenocarcinoma (papillary, tubular, mucinous, etc.), squamous and adenosquamouscell carcinoma, undifferentiated carcinoma, and rare tumors (small-cell carcinoma, sarcoma, melanoma and lymphoma). The most common type is adenocarcinoma with a rate of 80 to $95 \%$. Eighty percent of patients have also infiltration to the adjacent liver, while $50 \%$ are infiltrated to the portal vein, choledoc and other organs (colon, duodenum and jejunum). The five-year survival rate is very low in non-surgical patients, while it is $20 \%$ after resection (8). In gallbladder cancer, the most common site of extra-abdominal metastases is the lung. Cavitary lung metastasis was first described by Bristowe in 1871 (9). The most common malignancies leading to cavitary lung metastases include primary squamous-cell carcinoma of the larynx and carcinoma of the pharynx, tongue, cervix and skin $(10,11)$. Extra-abdominal metastases of gallbladder cancers are 55\% localized in the lungs $(12,13)$. While a systemic metastasis usually indicates that primary tumor is uncontrollable with a poor prognosis, isolated lung metastasis does not necessarily mean that the disease is always systemic and uncontrolled (14). Patients with an isolated pulmonary metastasis have a much better response to local and systemic treatment, compared to those with multi-organ metastases, and they must be evaluated distinctly based on this feature (15). A complete resection of pulmonary metastases may result in a mean five-year survival of 20 to $50 \%(16,17)$. It is usually very likely to detect metastases by routine chest $\mathrm{X}$-rays after treatment of the primary tumor. They usually appear with regular margins, sometimes in the form of multiple opacities. Patient with a confirmed or suspected metastasis in chest $\mathrm{X}$-ray should also be evaluated by computed tomography (CT) before surgery. Lymph nodes $3 \mathrm{~mm}$ insize can be seen as nodules on CT. Abecasis et al. (18) reported that the lesion was undetectable in plain radiographs in $20 \%$ of patients whose metastases were confirmed by CT.

There are relatively few case reports on cavitation in metastatic pulmonary tumors in the literature. Although metastatic pulmonary nodules are rare, a careful differential diagnosis should be performed in patients with a neoplastic disease. We believe that survival will improve by treatment of metastatic lesions which are confirmed by early biopsy procedure and resection.

\section{CONFLICTS OF INTEREST}

None declared.

\section{AUTHOR CONTRIBUTIONS}

Concept - M.Ç., S.G.Ç., T.T.B., Y.Ü., H.E.; Planning and Design - M.Ç., S.G.Ç., T.T.B., Y.Ü., H.E.; Supervision M.Ç., S.G.Ç., T.T.B., Y.Ü., H.E.; Funding - M.Ç., S.G.Ç.; Materials - M.Ç., S.G.Ç.; Data Collection and/or Processing - M.Ç., S.G.Ç.; Analysis and/or Interpretation M.Ç., S.G.Ç.; Literature Review - M.Ç., S.G.Ç.; Writing M.Ç., S.G.Ç.; Critical Review - M.Ç., S.G.Ç.

\section{YAZAR KATKILARI}

Fikir - M.Ç., S.G.Ç., T.T.B., Y.Ü., H.E.; Tasarım ve Dizayn - M.Ç., S.G.Ç., T.T.B., Y.Ü., H.E.; Denetleme M.Ç., S.G.Ç., T.T.B., Y.Ü., H.E.; Kaynaklar - M.Ç., S.G.Ç.; Malzemeler - M.Ç., S.G.Ç.; Veri Toplama ve/veya İşleme - M.Ç., S.G.Ç.; Analiz ve/veya Yorum M.Ç., S.G.Ç.; Literatür Taraması - M.Ç., S.G.Ç.; Yazıyı Yazan - M.Ç., S.G.Ç.; Eleştirel İnceleme - M.Ç., S.G.Ç.

\section{REFERENCES}

1. Yang XW, Yang J, Li L, Man XB, Zhang BH, Shen F, et al. Analysis of the relationships between clinicopathologic factors and survival in gallbladder cancer following surgical resection with curative intent. PLoS One 2012; 7:e51513. [CrossRef]

2. Dutta U. Gallbladder cancer: can newer insights improve the outcome? J Gastroenterol Hepatol 2012; 27:64253. [CrossRef] 
3. Jayaraman S, Jarnagin WR Management of gallbladder cancer. Gastroenterol Clin North Am 2010; 39:331-42. [CrossRef]

4. Goodman K, Wagman R, Ho AY. Cancer of the liver, bile duct, and gallbladder. In: Hope R, Roach M, Phillips $T$, eds. Leibel and Phillips Textbook of Radiation Oncology. 3rd ed. Philadelphia: Elselvier Saunders; 2010:82931 .

5. Lazcano-Ponce EC, Miguel JF, Munoz N, Herrero R, Ferrecio $C$, Wistuba II, et al. Epidemiology and molecular pathology of gallbladder cancer. CA Cancer J Clin 2001; 51:349-64. [CrossRef]

6. North JH Jr, Pade MS, Hong C, Rivera DE. Prognostic factors for adenocarcinoma gallbladder: an analysis of 162 cases. Am Surg 1998; 64:437-40.

7. Lin HT, Liu GJ, Wu D, Lou JY. Metastasis of primary gallbladder carcinoma in lymph node and liver. World J Gastroenterol 2005; 11:748-51. [CrossRef]

8. Zheng SS, Liang TB, Qin YS, Zhang M, Wang WL, Shen $Y$, et al. The long term result of management in 98 cases of gallbladder carcinomas. Zhonghua Wai Ke Za Zhi 2004; 7:517-9.

9. Gadkowski LB, Stout JE. Cavitary pulmonary disease. Clin Microbiol Rev 2008; 21:305-33. [CrossRef]

10. Seo JB, Im JG, Goo JM, Chung MJ, Kim MY. Atypical pulmonary metastases: spectrum of radiologic findings. Radiographics 2001; 21:403-17. [CrossRef]
11. Bristowe JS. Cancer involving pharynx, larynx, neighboring lymphatic glands and lungs. Trans Path Soc Lond $1871 ; 22: 132$.

12. Lemay M, Piro AJ. Cavitary pulmonary metastases. Ann Intern Med 1965; 62:59-66. [CrossRef]

13. Don C, Gray DG. Cavitating secondary carcinoma of the lung. J Can Assoc Radiol 1967; 18:310-5.

14. Piehler JM, Crichlow RW. Primary carcinoma of the gallbladder. Surg Gynecol Obstet 1978; 147:929-42.

15. Sons HU, Borchard F, Joel BS. Carcinoma of the gallbladder: autopsy findings in 287 cases and review of the literature. J Surg Oncol 1985; 28:199-206. [Cross$\underline{\text { Ref] }}$

16. Putnam JB. Pulmonary Metastases. In: Franco KL, Putnam $J B$, eds. Advanced therapy in thoracic surgery. Ontario: BC Decker Company; 1998:1 17-26.

17. Putnam JB. Secondary tumors of the lung. In: Shields TW, LoCicero J, Ponn RB, eds. General thoracic surgery. Fifth Ed. Philadelphia: Lippincott Williams\&Wilkins Company; 2000:1555-76.

18. Abecasis N, Cortez F, Bettencourt A, Costa CS, Orvalho $F$, de Almeida JM, et al. Surgical treatment of lung metastases: prognostic factors for long-term survival. J Surg Oncol 1999; 72:193-8. [CrossRef] 